\title{
GAMBARAN POLA MAKAN PADA WARGA DUSUN KRAMANAN, KABUPATEN BOJONEGORO
}

\section{(DIETARY PATTERN IN KRAMANAN SUB-VILLAGE, BOJONEGORO DISTRICT)}

\author{
Khansa Nadra \\ Departemen Promosi Kesehatan dan Ilmu Perilaku \\ Fakultas Kesehatan Masyarakat Universitas Airlangga \\ Email : nadra.khansa@fkm.unair.ac.id
}

INFO ARTIKEL :

Diterima Oktober 2018

Disetujui November 2018

Dipublikasikan Desember 2018

\begin{abstract}
This study provides an overview about the eating habits of the villagers Kramanan, Jatimulyo village, District Tambakrejo, Bojonegoro. The importance of the diet of people is the reason for the study was conducted. Health is one of the faktors that affect the quality of the people. It can be obtained either by the improvement of food and nutrition. Fulfillment of food and nutrition will form an independent human being, and a better quality so they will able to participate in development.the aim of this study was to determine the diet in the Kramanan sub-village. This study will describe the diet and causation of that habit. The research method is using descriptive approach. The datas are from interviews, observations, and also supported by secondary data. Results of the research is that the villagers in Kramanan have a habit of eating rice with vegetables and tempeh. Eating habits of the villagers are easy to trigger the buildup of purin. Iif these substances accumulate in the blood or joints, it will causes joint pain. Observations and interviews also show that citizens often complain of headaches, muscle aches and joint pain. It is not solely due to the consumption of food, but also because the physical activity of the villagers.
\end{abstract}

Keyword: dietary pattern, Kramanan Sub-Village 


\begin{abstract}
ABSTRAK
Penelitian ini berisi tentang gambaran kebiasan makan pada warga dusun Kramanan, desa Jatimulyo, Kecamatan Tambakrejo, Kabupaten Bojonegoro. Pentingnya pola makan masyarakat adalah alasan penelitian ini dilakukan. Kesehatan adalah salah satu faktor yang mempengaruhi kualitas dari manusia itu sendiri. Hal ini dapat diperoleh salah satunya dengan perbaikan pangan dan gizi. Terpenuhinya kebutuhan pangan dan gizi akan membentuk manusia yang mandiri, berkualitas dan akan lebih mampu berperan serta dalam pembangunan.Tujuan dari penelitian ini adalah untuk mengetahui pola makan di dusun Kramanan. Penelitian ini akan mendeskripsikan mengenai pola makan serta sebab-akibat dari kebiasaannya itu. Metode penelitian menggunakan pendekatan deskriptif dengan pengambilan data dari wawancara, observasi, dan di dukung oleh data sekunder. Hasil penelitian yang dilakukan adalah bahwa warga dusun Kramanan memiliki kebiasaan makan nasi dengan lauk sayur dan tempe. Kebiasaan makan tersebut mudah untuk memicu penumpukan zat purin yang apabila zat tersebut menumpuk dalam darah atau persendian, akan menyebabkan nyeri sendi. Hasil observasi dan wawancara juga membuktikan bahwa warga sering mengalami keluhan pusing, nyeri otot dan nyeri sendi. Hal ini bukan semata-mata karena konsumsi makanan, melainkan juga karena aktifitas fisik warga.
\end{abstract}

Kata Kunci : Pola Makan , Dusun Kramanan 


\section{PENDAHULUAN}

Kesehatan adalah hak seluruh mahluk hidup. Manusia yang sehat adalah manusia yang bisa melakukan sesuatu yang produktif. Menurut WHO, Sehat adalah suatu keadaan yang lengkap dari sehat fisik, mental dan sosial, serta tidak hanya bebas penyakit atau kecacatan, sehingga seseorang dapat bekerja secara produktif. Dalam UU No 36 Tahun 2009 Tentang Kesehatan bab 1 pasal 1 ayat 1 disebutkan bahwa Kesehatan adalah keadaan sehat, baik secara fisik, mental, spritual maupun sosial yang memungkinkan setiap orang untuk hidup produktif secara sosial dan ekonomis.

Pembangunan di Indonesia sangat besar di bidang perekonomian. Peningkatan sumber daya manusia sangat dibutuhkan dalam hal ini. Kesehatan merupakan faktor penting dalam peningkatan kualitas sumber daya manusia. Hal ini dapat diperoleh salah satunya dengan perbaikan pangan dan gizi. Apabila masyarakat memiliki kecukupan pangan dan gizi, maka masyarakat akan dapat menjadi lebih berkualitas dan berperan dalam pembangunan.

Konsumsi pangan yang sehat adalah adalah makanan yang mengandung gizi seimbang. Untuk itu perlu bahan makanan yang bervariasi agar mendapatkan zat gizi yang lengkap. Sayur dan buah beperan sangat penting dalam proses metabolisme. Menu seimbang adalah menu yang terdiri dari beraneka ragam makanan dalam jumlah dan proporsi yang sesuai, sehingga memenuhi kebutuhan gizi seseorang guna pemeliharaan dan perbaikan sel-sel tubuh dan proses kehidupan serta pertumbuhan dan perkembangan (Almatsier, 2004). Menurut Harper (1986), pola makan (dietary pattern) adalah cara yang ditempuh seseorang atau sekelompok untuk memilih makanan dan mengkonsumsinya sebagai reaksi terhadap pengaruh fisiologis, psikologis, budaya dan sosial

Jumlah makanan yang masuk juga perlu diperhatikan agar tidak berlebih. Karena konsumsi makanan yang berlebihan dapat menyebabkan obesitas. Obesitas atau kegemukan 
adalah ketidakseimbangan jumlah makanan yang masuk dibanding dengan pengeluaran energi oleh tubuh. Obesitas apabila tidak ditangani dapat menyebabkan komplikasi dengan penyakit lain seperti penyakit jantung, penyakit paru, penyakit tulang, dan sebagainya. Selain itu, obesitas ini juga disebabkan oleh beberapa faktor. Misalnya, pola makan yang salah (terbiasa makan makanan berlemak tinggi), gaya hidup yang kurang gerak, stres yang dilarikan pada makanan, dan faktor keturunan. Selain itu makanan tertentu juga akan menyebabkan meningkatnya penyakit tertentu sesuai dengan kandungan yang di makan oleh orang tersebut.

Pentingnya pola makan masyarakat adalah alasan penelitian ini dilakukan. Selain itu pengambilan kasus di dusun Kramanan ini adalah karena belum ada peneliti yang meneliti tempat ini. Dan juga menurut Ds. Suyoto M.si sebagai bupati Bojonegoro, desa Jatimulyo ini merupakan salah satu desa dengan permasalahan kesehatan yang lebih kompleks dibandingkan dengan desa lain di Bojonegoro. Hal tersebut dikatakan saat acara penerimaan mahasiswa praktek kerja lapangan (PKL) di balai bupati Bojonegoro.

\section{METODE}

Penelitian ini menggunakan pendekatan kualitatif. Data yang digunakan adalah primer dan sekunder. Data primer diperoleh dari hasil observasi, mengobrol informal, dan indepth interview. Data sekunder didapatkan dari puskesmas Tambakrejo, mantri dan kepala desa Jatimulyo, Bojonegoro. Penelitian ini dilakukan pada tanggal 20 Juli 2016 23 Agustus 2016 di Dusun Kramanan, Desa Jatimulyo, Kecamatan Tambakrejo, Kabupaten Bojonegoro, Jawa Timur.

Penelitian dilakukan kepada seluruh warga dengan cara mendatangi kerumah atau door to door, lalu mewawancarai orang yang bersangkutan, baik kepala keluarga, istri, ataupun anak yang sudah dewasa. Observasi juga dilakukan pada warung makan, dan juga beberapakali memperhatikan cara memasak ibu dusun yang sekaligus merupakan ketua kader di dusun tersebut. 


\section{HASIL PENELITIAN}

Berdasarkan data sekunder yang kami dapatkan dari kepala dusun Kramanan, berikut adalah jumlah warga dusun Kramanan pada tahun 2015 dalam tabel 1.

Tabel 1. Daftar Kk Dan Jiwa Dusun Kramanan Tgl 20 - 02 - 2015

\begin{tabular}{|l|l|l|l|l|}
\hline RT & KK & $\begin{array}{l}\text { Jumlah } \\
\text { Jiwa }\end{array}$ & L & P \\
\hline 11 & 93 & 310 & 158 & 152 \\
\hline 12 & 84 & 286 & 149 & 137 \\
\hline TOTAL & $\mathbf{1 7 7}$ & $\mathbf{5 9 6}$ & $\mathbf{3 0 7}$ & $\mathbf{2 8 9}$ \\
\hline Sumber : & data $\quad$ sekunder kepala dusun \\
\hline
\end{tabular}

Kramanan, 2015

Pada tabel 1 dapat dilihat bahwa jumlah responden di dusun tersebut adalah sebanyak 596 jiwa. Jumlah total adalah 307 untuk laki-laki dan 289 perempuan. Saat kami melakukan wawancara dan observasi, kami menemukan ada 414 jiwa saja yang tercatat, dan hanya ada $140 \mathrm{KK}$ yang dapat kami temukan di lokasi. Kendalanya adalah banyak warga yang merantau bersama keluarga, sehingga tidak terdata. Dan juga banyak warga yang telah pindah ke kota. Selain itu ada juga warga yang baru menikah, atau pun hanya pindah dari dusun lain ke dusun Kramanan, namun belum mengurus KK. Sehingga kami tidak masukkan kedalam responden penelitian.

Dari data primer yang kami temukan, dari seluruh total populasi ada 3 orang yang mengalami obesitas, dan semuanya adalah wanita yang berusia diatas 40 tahun. Hasil wawancara kami tentang kebiasaan makan warga hampir seluruhnya mengatakan sayur dan nasi, dan sebagian besar juga mengatakan nasi, sayur, tahu dan tempe. Pangan hewani jarang dikonsumsi oleh warga di dusun Kramanan.

Cara memasak sayur warga yang kami amati yaitu, warga selalu menambahkan penyedap rasa. Selain itu kami mendapati bahwa warga memiliki kebiasaan untuk memasak sayur hingga layu dan juga sayur yang paling sering dimasak adalah bayam. Jenis makanan yang umum dimakan adalah nasi pecel pada pagi hari dengan sayur saja atau terkadang ada juga yang memakannya dengan tempe. Ada juga yang memakan pecel dengan telur namun jarang. Pada siang dan malam hari umumnya warga memasak satu jenis makanan saja. Jenis makanan yang dimasak biasanya adalah sayur sop, bihun, bakwan/ote-ote, tumisan sayur, tumisan tempe, tumisan tahu, tempe goring tepung, tempe goreng, 
tahu goreng, lodeh, dan sayur bening. Untuk makanan warga sendiri, semua makanan tersebut yang dimasak tidak dicampur dengan daging apapun, kecuali pada keadaan tertentu.

Higienitas pada warga saat memasak kurang diperhatikan, bagi mereka yang penting sayur sudah dicuci menggunakan air. Tanpa memperdulikan apakah itu air mengalir atau tidak. Dan penyimpanan alat masak dan makan masih terbuka dan sangat mudah tercemar oleh hewan seperti tikus, cicak, kecoa, lalat, dan terkadang kucing. Dan warga cenderung untuk tidak mencuci sebelum digunakan.

Buah yang sering dimakan oleh warga yaitu pisang. Selain itu ada juga yang mudah ditemukan yaitu jeruk dan semangka. Sebagian warga memiliki pohon sendiri untuk pisang. Semangka dan jeruk biasa dimakan pada saat acara tertentu. Untuk membungkus makanan, warga biasa menggunakan daun jati seperti pada gambar 1 . Walaupun ada yang menggunakan kertas minyak cokelat ataupun daun pisang.

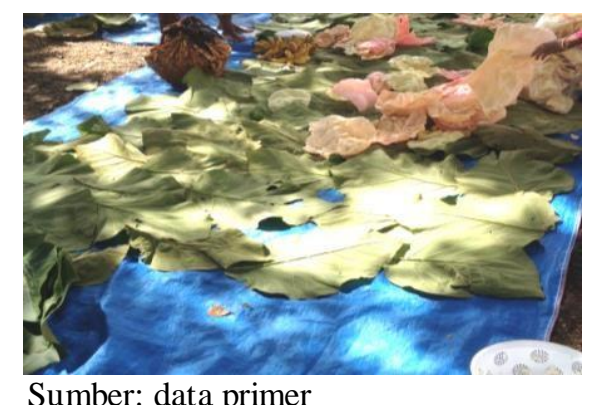

Gambar 1.Daun Jati

Dari gambar 1 tersebut dapat terlihat daun jati yang berserakan. Kegiatan itu merupakan kegitan sedekah bumi, dimana para warga mengumpulkan berbagai macam makanan lalu dibagi kepada seluruh warga. Kegiatan ini dilakukan sebagai adat warga setempat ketika musim panen.

\section{PEMBAHASAN}

Berdasarkan karakteristik usia di dusun kraman memiliki rentang usia yang luas dari bayi hingga lansia. Faktor usia dapat mempengaruhi pola makan begitu juga penyakit degeneratif. Pada saat penelitian dilakukan, tidak ditemukan perbedaan yang signifikan pada pola makan anak, remaja, maupun dewasa. Namun ada food taboo yang masih menjadi kepercayaan warga dusun Kramanan. Bagi para warga, remaja perempuan dilarang memakan ati ayam karena kepercayaan yang sudah turuntemurun. 
Kejadian Obesitas yang kami temukan di Dusun Kramanan terjadi hanya pada wanita diatas 40 tahun, dan total warga yang obesitas adalah tiga orang. Dua orang diantaranya mengalami kenaikan berat badan ketika menggunakan alat kontrasepsi, jadi pola makan bukan alasan utama kenaikan berat badan, melainkan hormonal. Pada saat kami melakukan penelitian selama satu bulan, kami merasa kesulitan karena akses ke pasar jauh dan perlengkapan yang kami bawa terbatas. Warga mengatakan bahwa kebiasaan warga disini adalah menanam sendiri dan memakan apa yang dimiliki. Dan terkadang ketika butuh bahan masakan yang lain baru membeli di warung yang berada disekitar. Tukang sayur juga berkeliling rutin, walau terkadang ada hari libur untuk tukang sayur tersebut.

Makanan utama yang biasa dikonsumsi oleh warga adalah nasi, sayur, dan tempe. Ada seorang warga yang kami wawancara dan mengatakan bahwa tempe termasuk bahan makanan yang tegolong mahal untuk dibeli, sehingga keluarga tersebut hanya memakan tempe ketika memiliki uang yang cukup. Ada juga yang mengatakan bahwa tempe buakanlah makanan yang mahal, melainkan ayam.

Pada saat wawancara kami menemukan bahwa ada warga yang apabila ingin memakan ayam, mereka memotong ayam peliharaannya sendiri walaupun ada yang menjual ayam di pasar. Pada saat kami tinggal dan merasakan kehidupan warga, kami jarang mendapatkan makanan hewani harus membeli di warung tertentu atau ke pasar. Makanan hewani yang paling mudah ditemukan adalah ayam dan ikan. Ada sebuah warung di dusun Kramanan yang menjual mie ayam, dan nasi ayam lada hitam. Warung tersebut adakah warung satu-satunya di dusun Kramanan yang menjual pangan hewani setiap hari.

Penyedap rasa yang digunakan oleh warga di dusun Kramanan tidak selalu sama namun selalu diantara Royco, Masako, ataupun sasa.Penyedap rasa yang digunakan yaitu MSG. Monosodium glutamate (MSG) adalah bentuk garam dari asam glutamat, di mana asam glutamat sendiri merupakan asam amino non-essensial yang menjadi bahan baku sintesis asam amino lain. MSG masih sering menimbulkan kontroversi karena banyak penelitian yang mengatakan 
bahaya namun ada juga yang mengatakan aman. Sebenarnya faktor yang memicu terjadinya bahaya dalam penggunaan MSG adalah jumlah atau dosis dari penggunaan MSG tersebut. Apabila dikonsumsi berlebihan akan menimbulkan efek seperti pusing, mual, hipertensi, sesak nafas, dan sebagainya tergantung respon tubuh. Namun secara umum MSG dapat dikategorikan aman menurut JECFA (Joint Expert Committee on Food Additives).

Batasan aman yang pernah dikeluarkan oleh badan kesehatan dunia World Health Organization (WHO), asupan MSG per hari sebaiknya sekitar $0-120 \mathrm{mg} / \mathrm{kg}$ berat badan. Jadi, jika berat seseorang $50 \mathrm{~kg}$, maka konsumsi MSG yang aman menurut perhitungan tersebut 6 gr. Dalam Peraturan Kepala Badan Pengawas Obat dan Makanan No 23 Tahun 2013 tentang Batas Maksimum Penggunaan Bahan Tambahan Pangan Penguat Rasa halaman 9 dapat dilihat bahwa tidak ada batasan spesifik mengenai MSG.

Memasak sayur perlu perlakuan khusus. Karena apabila salah mengolah, kandungan gizi dalam sayur tersebut dapat berkurang bahkan rusak. Konsumsi sayuran yang masih segar tanpa dimasak memang baik, namun tidak semua orang bisa mengkonsumsi sayuran yang mentah. Karena tidak semua bakteri akan mati hanya dengan mencuci sayuran tersebut. Maka dari itu, perlu diketahui cara memasak sayur yang benar dan sehat.

Memasak sayur dapat dilakukan dengan berbagai cara seperti memanggang, mengukus, presto, menumis, merebus, dan sebagainya. Untuk memanggang sayuran lebih baik disertai kandungan air yang tinggi agar tidak kering. Sayuran yang bisa dipanggang contohnya adalah tomat, kentang, dsb. Mengukus sayur adalah cara terbaik untuk memasak seluruh tipe sayuran, karena tidak langsung bersentuhan dengan minyak ataupun godokan air. Sehingga dapat mempertahankan zat gizi yang terkandung, dan dapat mematangkan sayur dalam waktu singkat. Presto tidak dianjurkan dalam memasak sayur, karena apabila terlalu lama dengan tekanan tinggi, sayur akan cepat lembek dan zat gizinya berkurang.

Menumis dan merebus menjadi kebiasaan dalam cara memasak sayur pada warga di dusun Kramanan. Warga biasa memasak sayuran ini sampai sayur layu. Hal ini dikarenakan 
persepsi warga yang menganggap bahwa sayur yang matang (layu) lebih layak untuk dimakan karena terlihat berbeda daripada yang masih segar. Dan terlihat matang, sehingga warga memakan dengan nyaman. Selain itu hal ini memang sudah dilakukan turuntemurun dan seluruh warga menganggap hal tersebut adalah hal yang benar. Padahal dengan memasak sayur seperti itu, zat gizi yang dikandung akan sangat berkurang. Menumis sebaiknya diperhatikan waktu dan caranya. Terkadang vitamin larut lemak akan ikut bersama minyak di tumisan tersebut, sehingga apabila minyak dibuang, makan vitamin larut lemak pun akan ikut terbuang. Merebus sayur adalah cara yang paling sering menimbulkan risiko. Dengan cara yang salah, maka zat gizi akan banyak terbuang. Merebus saur sebaiknya menunggu air hingga mulai mendidih, lalu masukkan sayur dan angkat. Apabila terlalu lama, maka beberapa zat gizi akan menguap.

Pola makan di dusun Kramanan ini bisa dikatakan monotone atau kurang bervariasi. Karena bahan utama hanya nasi, sayur, dan tempe. Tempe adalah pangan tradisional khas Indonesia yang berasal dari kedelai.
Tempe terdapat di pasar tradisional maupun modern. Di dusun Kramanan tempe merupakan lauk yang sangat sering dikonsumsi. Walaupun ada beberapa keluarga yang jarang mengkonsumsi tempe karena menganggap tempe mahal. Warga lebih sering memakan apa yang ditanamnya. Manfaat tempe bagi kesehatan sebenarnya tidak perlu diragukan lagi. Efek antioksidan pada tempe sebenarnya merupakan hasil dari efek sinergis tocopherol atau vitamin E pada kedelai dengan asam amino yang dibebaskan selama fermentasi oleh rhizopus oligosporus yang mengakibatkan timbulnya aktivitas lipase sehingga kadar asam lemak bebas pada tempe lebih tinggi dibanding kedelai. Potensi tempe untuk mencegah oksidasi lipid juga lebih besar dibanding tocopherol.

Sayuran yang dimakan sebagian besar adalah bayam, buncis, kembang kol, kangkung. Sayuran lain yang biasa dimakan yaitu tomat, wortel, kentang, namun tidak sering. Dari hasil observasi dan wawancara, warga sering mengalami keluhan nyeri sendi dan otot. Penyebab hal tersebut bisa dari berbagai faktor. Mulai dari faktor aktifitas fisik dan makanan. Dari 
aktifitas fisik dapat terlihat jelas bahwa warga di dusun Kramanan mengangkut hasil panen dua kali sehari. Jarak yang ditempuh berkisar antara 1-5 Kilometer dengan beban yang diangkat 20-25 Kilogram. Untuk faktor makanan juga dapat disebabkan oleh konsumsi makanan yang mengandung tinggi purin. Ketika konsumsi zat purin besar, maka akan terjadi peningkatan kadar asam urat dalam tubuh yang membuat ginjal tidak mampu membuang kelebihan asam urat tersebut. Rasa nyeri pada sendi terjadi akibat banyaknya Kristal asam urat yang menumpuk di persendian tersebut. Makanan yang dikonsumsi oleh warga di dusun Kramanan memiliki kandungan zat purin yang tinggi, seperti tempe, kembang kol, bayam, daun singkong dan buncis.

Warga Dusun Kramanan sering memasak makanan yang mereka peroleh dari lahannya sendiri. Mereka hanya membeli ke tukang sayur atau pasar apabila ada bahan makanan yang kurang dan perlu. Dari mulai beras, kacang-kacangan hingga sayuran warga lebih memilih untuk menanam sendiri. Selain cara memasak, kebersihan dari sebuah makanan harus diperhatikan. Dari awal proses produksi hingga konsumsi. Pengolahan dan penyimpanan makanan harus perhatikan agar tetap terjaga kebersihannya. Warga di dusun Kramanan kurang waspada akan adanya binatang baik kecil maupun besar yang berpotensi mencemari dapur. Sehingga makanan dan alat masak menjadi tercemar. Alat masak dan alat makan di cuci dengan air yang tidak mengalir adalah salah satu isu yang wajar di dusun tersebut. Karena tidak adanya sosialisasi dan juga fasilitas yang memadai. Setelah mencuci selalu dibuang di sawah atau kali, karena belum adanya ISPAL di daerah tersebut.

Penyimpanan alat makan dan alat masak berada di tempat terbuka. Selain itu rumah di dusun Kramanan sebagian besar beralaskan tanah, ada sebagian lain yang berupa semen, kayu, dan paving. Namun untuk dapur hampir seluruhnya beralaskan tanah. Hal ini terjadi karena tanah di Bojonegoro terkadang bergerak, sehingga apabila menggunakan lantai, akan retak dan rusak. Hal ini akan mempermudah hewan untuk mencemari alat makanan ataupun alat masak. Maka dari itu untuk penyimpanan alat makanan dan masak lebih baik apabila tertutup, atau 
bisa juga dapat dicuci sebelum digunakan. Karena pada saat menyimpan alat masak dan alat makan ditempat terbuka, akan mudah terjadi pencemaran. Seperti kecoa, kucing, lalat, dsb.

Untuk makanan sebagian ditutup dengan tudung saji, dan ada yang ditutup dengan Koran, daun, dan ditutup dengan alat makan. Tidak semua warga memiliki kulkas untuk menyimpan makanan, sehingga makanan yang tidak habis hari itu biasanya akan diolah kembali dan dimanfaatkan untuk pakan hewan. Nasi yang dimasak masih yang menggunakan cara tradisional yaitu menggunakan panci kukus dan memasak di atas kayu bakar. Biasanya jumlah nasi yang dimasak banyak, dan sisanya akan dikeringkan dan diolah kembali. Hasil olahan nasi ini bisa dijadikan makanan untuk cemilan warga, dan juga ada yang diolah untuk diberikan kepada ayam.

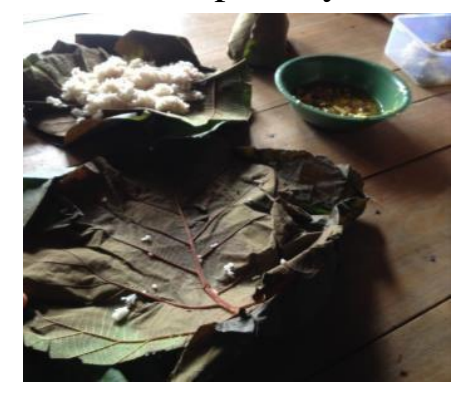

Sumber: Data prime

Gambar 2 Daun Jati untuk Nasi Bungkus
Desa Jatimulyo merupakan salah satu daerah penghasil jati terbanyak di Bojonegoro. Di dusun Kramanan terdapat juga pengrajin jati. Karena produksi jati yang tinggi, daun jati juga dimanfaatkan oleh warga. Selain itu bagi warga, makanan yang terbungkus oleh daun jauh lebih nikmat dibanding dengan dibungkus oleh kertas maupun plastic. Aroma makanan yang terbungkus oleh daun akan lebih khas. Membungkus makanan dengan daun akan lebih ramah lingkungan karena daun sebagai bahan organic yang mudah untuk diurai. Sedangkan plastic lebih sulit untuk diurai karena merupakan bahan sintetis. Namun di dusun Kramanan masih banyak tempe yang dibungkus dengan plastic. Padahal tempe jika dibungkus dengan plastic yang rapat akan mengganggu proses fermentasi dan mempengaruhi kualitas tempe. Tempe yang dibungkus dengan daun pisang akan memiliki sirkulasi udara yang baik darena dalam daun tersebut terdapat rongga udara. Aroma dari tempe pun akan lebih harum dan tak berbau tengik karena ada kandungan polifenol.

Konsumsi buah bagi warga di dusun Kramanan bukanlah sebuah keharusan. Mereka tidak setiap hari 
mengkonsumsi buah. Namun sebagian besar warga menyediakan buah di rumahnya. Buah yang paling sering ditemukan di rumah warga yaitu pisang. Pisang sangat baik untuk tubuh karena pisang mengandung kandungan gizi yang meliputi lemak protein, karbohidrat, serat, zat besi, fosfor, kalsium, vitamin $\mathrm{C}$, vitamin $\mathrm{B}$, dan vitamin A. Di dusun Kramanan, buah pisang juga dikonsumsi oleh ibu hamil. Manfaat pisang bagi ibu hamil juga dibutuhkan untuk perkembangan janin di dalam rahim karena mengandung asam folat. Namun karena memiliki kalori tinggi, ada baiknya untuk membatasi jumlah pisang yang dikonsumsi.

buah lain yang mudah ditemukan yaitu jeruk dan semangka. Namun ini hanya akan ditemukan pada saat acara khusus di dusun Kramanan. Para ibu PKK di dusun tersebut setiap jum'at siang akan mengadakan acara tahlilan dan disana akan ada beragam makanan. Dan buah yang biasa disuguhkan adalah semangka. Warga sangat senang memakan buah semangka. Jeruk terkenal mengandung vitamin $\mathrm{C}$ yang menyehatkan. Namun orang-orang selalu mengira bahwa jeruk merupakan vitamin $\mathrm{C}$ tertinggi, padahal nyatanya banyak buah lain yang lebih tinggi kandungan vitamin $\mathrm{C}$ nya. Selain itu buah yang dikonsumsi oleh warga yaitu semangta. Semangka kaya akan air, semangka mengnadung $92 \%$ air. Semangka adalah salah satu buah dengan sumber vitamin A dan $\mathrm{C}$.

Buah yang dikonsumsi oleh warga di dusun Kramanan adalah buah yang banyak mengandung vitamin $\mathrm{c}$ dan zat gizi lain yang dibutuhkan untuk metabolism tubuh. Serat makanan yang berasal dari sayuran, kacang-kacangan dan buah-buahan merupakan subtansi yang tidak saja memperbaiki flora usus melalui pertumbuhan bakteri lactobacillus, tetapi juga memberi dampak positif pada unsur kesehatan lainnya seperti pencegahan penyakitpenyakit degeneratif

\section{KESIMPULAN}

Pola makan di dusun Kramanan ini kurang bervariasi. Karena bahan utama hanya nasi, sayur, dan tempe. Makanan yang dikonsumsi oleh warga di dusun Kramanan memiliki kandungan zat purin yang tinggi, seperti tempe, kembang kol, bayam, daun singkong dan buncis. Selain itu cara memasak sayur di dusun Kramanan ini adalah memasak sayur 
tersebut hingga layu. Selain itu warga selalu menambahkan MSG pada tiap masakan dengan jumlah yang tidak sedikit. Biasanya 1 bungkus dalam 1 panci sayuran ukuran sedang.

Kejadian Obesitas yang kami temukan di Dusun Kramanan terjadi hanya pada wanita diatas $40^{\text {th }}$, dan total warga yang obesitas adalah 3 orang. Untuk nyeri sendi dan otot yang banyak dikeluhkan oleh warga dapat disebabkan oleh aktifitas fisik dan juga konsumsi makanan yang banyak mengandung purin.

SARAN

Untuk penelitian selanjutnya diharapkan untuk meneliti lebih dalam mengenai hubungan kebiasaan makan dengan kesehatan atau dengan berbagai penyakit degenerative.

\section{DAFTAR PUSTAKA}

Almatsier, S, 2004. Prinsip Dasar Ilmu Gizi. Pt. Gramedia Pustaka Umum. Jakarta.

Astuti, N.P., 2009. Sifat Organoleptik Tempe Kedelai Yang Dibungkus Plastik, Daun Pisang Dan Daun Jati

(Doctoral Dissertation, Universitas Muhammadiyah Surakarta).
Azwar, A., 2004. Kecenderungan Masalah Gizi Dan Tantangan Di Masa Datang. Disamping Dalam Advokasi Perbaikan Gizi Menuju Kadarzi.

Azwar, A. And Ri, D.K., 2004. Tubuh Sehat Ideal Dari Segi Kesehatan. Inseminar Kesehatan Obesitas. Senat Mahasiswa Fakultas

Kesehatan Masyarakat Ui, Sabtu (Vol. 15).

Cahanar, P. And Suhanda, I., 2006. Makan Sehat Hidup Sehat. Penerbit Buku Kompas.

Devi, N., 2010. Nutrition And Food: Gizi Untuk Keluarga. Penerbit Buku Kompas.
Daftar Komposisi Zat Gizi Pangan Indonesia, Depkes Ri, 1998

Harper, L. J. Et Al., 1986. Pangan, Gizi Dan Pertanian. Penerjemah Suhardjo, Uipress, Jakarta

$\begin{array}{ccrr}\text { Jecfa } & \text { (Joint } & \text { Fao/Who } & \text { Expert } \\ \text { Committee } & \text { On } & \text { Food } \\ \text { Additives) } & & (1974) .\end{array}$


Toxicological Evaluation Of Certain

Food Additives With A Review Of

General Prinsiples And Of

Specifications. Geneva: Fao And

Who.

Kant, Imanuel., Dkk. 2013. Gambaran Kebiasaan Makan Masyarakat Di Perumahan Allandrew Permai Kelurahan Malalayang I Lingkungan $X i$ Kota Manado. Ilmu Kedokteran Komunitas Fakultas Kedokteran Universitas Sam Ratulangi.

Khasanah, N., 2012. Waspadai Beragam Penyakit Degeneratif Akibat Pola Makan. Jogjakarta: Laksana.

Leonard V P. Linda H C And Jean Y Liu. Antioxidant Potential Of Tempeh As Compared To Tocopherol. Journal Of Food Science 1988; 36:798-799

Maulana, H.D., Sos, S. And Kes, M., 2009. Promosi Kesehatan. Egc.

Pedoman Umum Gizi Seimbang (Pugs), Direktorat Gizi Masyarakat, Ri.

Santoso, I.A., 2011. Serat Pangan (Dietary Fiber) Dan Manfaatnya Bagi Kesehatan. Magistra, 23(75), p.35.
Soejoeti, S.Z., 2005. Konsep Sehat, Sakit Dan Penyakit Dalam Konteks Sosial Budaya. Majalah Cermin Dunia Kedokteran, (149).

Trisna, I. And Hamid, S., 2009. FaktorFaktor Yang Berhubungan Dengan Obesitas Sentral Pada Wanitadewasa (30-50 Tah Un) Di Kecamatan Lubuk Sikaping Tahun 2008. Jurnal Kesehatan Masyarakat Andalas, 3(2), Pp.68-71.

Utari, D.M., 2010. Kandungan Asam Lemak, Zink, Dan Copper Pada Tempe, Bagaimana Potensinya Untuk Mencegah Penyakit Degeneratif?. Gizi Indonesia, 2(33).

Utari, D.M., 2010. Kandungan Asam Lemak, Zink, Dan Copper Pada Tempe, Bagaimana Potensinya Untuk Mencegah Penyakit Degeneratif?. Gizi Indonesia, 2(33).

Undang-Undang Tentang Kesehatan, Uu Nomor 36 Tahun 2009 Lembaran Negara Republik Indonesia No. 144 Tahun 2009, Tambahan Lembaran Negara Republik Indonesia No. 5063. 